\title{
CHARISTHEO
}

Jurnal Teologi dan Pendidikan Agama Kristen

Sekolah Tinggi Teologi Anugrah Indonesia

Print ISSN: 2541-5247

http://e-journal.anugrah.ac.id/index.php/JCH

Vol. 1 No. 1, September 2021

Submitted: 2021-07-18

Reviewed: 2021-08-03

Accepted: 2021-08-12

\section{TELAAH MEMAKNAI PENYERTAAN ALLAH DALAM BINGKAI TEOLOGI PENTAKOSTA}

\author{
Kosma Manurung \\ STT Intheos Surakata \\ Email Correspondence: ykosma@yahoo.com
}

\begin{abstract}
Pentecostals are people who build their understanding of faith on the basis of a practical life that conforms to the Bible. The Bible gives an illustration of God's desire to be with believers. Immanuel is a term that refers to the existence of God who accompanies His people and is manifested by the presence of the Lord Jesus Himself (Matt. 123). This article's research specifically wants to highlight how Pentecostal theology interprets God's inclusion. The method used in this research is descriptive and literature review. How the inclusion of God in the lives of people whom the Bible believes in is discussed in such depth as the inclusion of God in the lives of Joseph, Moses, and Daniel. This article also discusses the real form of God's participation in the person and ministry of the Lord Jesus the gospel. The research results show that God's participation is the desire of God's heart to be present in the daily lives of believers as His chosen people. The presence of Allah also means God's care and protection. An understanding of God's presence awakens faith to believe confidently and live for God.
\end{abstract}

Keywords: immanuel; god inclusion; pentecost; pentecostalism; pentecostal theology

\begin{abstract}
ABSTRAK
Kaum Pentakosta adalah kaum yang membangun pemahaman iman mereka berdasarkan kehidupan praktis yang menyesuaikan dengan Alkitab. Alkitab memberikan gambaran tentang kerinduan Allah untuk menyertai orang percaya. Imanuel merupakan sebutan yang mengacu pada keberadaan Allah yang menyertai umat-Nya dan di wujud nyatakan oleh kehadiran Tuhan Yesus sendiri (Mat. 123). Penelitian artikel ini secara khusus ingin menyoroti bagaimana teologi Pentakosta memaknai penyertaan Allah. Metode yang digunakan dalam penelitian ini adalah deskriptif dan kajian literatur. Bagaimana penyertaan Allah dalam kehidupan orang percaya yang dicatat oleh Alkitab diulas secara mendalam seperti penyertaan Allah dalam kehidupan Yusuf, Musa, dan Daniel. Artikel ini juga mengulas wujud nyata penyertaan Allah dalam diri dan pelayanan Tuhan Yesus yang dicatat Injil. Hasil penelitian memaparkan bahwa penyertaan Allah merupakan kerinduan hati Allah untuk hadir dalam keseharian hidup orang percaya sebagai umat pilihan-Nya. Penyertaan Allah juga berarti pemeliharaan Allah dan perlindungan Allah. Pemahaman akan penyertaan Allah ini membangkitkan iman untuk dengan yakin mempercayai dan hidup bagi Allah.
\end{abstract}

Kata Kunci: imanuel; penyertaan allah; pentakosta; pentakostalisme; teologi pentakosta 


\section{PENDAHULUAN}

Manusia bukanlah sekedar mahluk sosial seperti yang digambarkan Aristoteles dalam Zoon Politicon melainkan manusia juga adalah mahluk spritual dan sebagai mahluk spritual manusia berusaha terhubung dengan sesuatu diluar dirinya yang dianggap memiliki kekuatan atau kemampuan yang melebihi dirinya. (Xiao, 2018, p. 94; Pradipta, 2019, p. 47) Hal ini juga bisa dimaknai bahwa jauh didalam diri manusia ada keinginan untuk terhubung dengan sesuatu yang bersifat ilahi atau yang bisa mereka anggap Allah yang memiliki kekuatan yang melebihi kekuatan manusia ataupun yang bisa dibayangkan oleh manusia. Dari Animatisme, animisme, dinamisme, dan agama suku sampai agama Abrahamik membuktikan bahwa manusia sebagai mahluk spritual ini memiliki rekam jejak selama tinggal di bumi berusaha dengan pencariannya untuk terhubung dengan kekuatan yang lebih tinggi.(Tamrin, 2019, p. 71)

Alkitab memberikan gambaran yang berbeda tentang Allah dan pencarian manusia ini, dalam konteks Alkitab bukanlah manusia yang mencari Allah melainkan Allah-lah yang terlebih dulu memiliki ide untuk mencari manusia. (Tembay \& Eliman, 2020, p. 33) Pemberontakan manusia ditaman Eden yang berakibat pengusiran memberikan gambaran bagaimana melalui kejatuhan manusia ini sebuah hubungan spritual terputus, manusia kehilangan akses untuk bersekutu dengan Allah.(Manurung, 2020c, p. 94) Terhadap dampak pemberontakan yang berakibat terputusnya hubungan ini, Allah mengambil inisiatif untuk terus berkomunikasi dengan manusia.(Hannas \& Rinawaty, 2019, p. 55) Allah mendatangi Abraham dan memanggilnya untuk menjadikannya bapa iman yang melalui imannya terhadap Allah menjadi berkat bagi segala bangsa dan sepanjang apa yang ditulis oleh Alkitab berkali-kali Allah berusaha membangun relasi dengan umat pilihan-Nya.(Rouw, 2017, p. 170)

Alkitab sebagai manual book dalam kehidupan orang percaya mengambarkan dengan sangat jelas bagaimana Allah menyertai umatnya. (Manurung, 2019, p. 37) Alkitab mengambarkan bagaimana Allah menyertai Yusuf dalam setiap proses kehidupannya dan membuat segala yang dikerjakan Yusuf berhasil. (Hendi, 2017, p. 29) Penyertaan Allah yang menyerai Musa menguatkan dan memampukan musa dalam tugas berat yang diemban oleh Musa untuk membawa orang keluar dari tanah mesir dan masuk ke tanah Perjanjian. (Lumingkewas, 2019, p. 338) Daniel hanyalah seorang anak muda yang merupakan tawanan yang diangkut ke Babel karena Yerusalem ditaklukan, dengan kata lain Daniel hanyalah seorang tawanan yang secara manusia waktu itu tidak mungkin berhasil, namun penyertaan Allah dalam hidup Daniel membuat Daniel menjadi orang 
penting di pemerintahan Babel waktu itu. (KALAMPUNG, 2019, p. 170) Perjanjian Baru sendiri lewat pernyataan malaikat yang datang dalam mimpi Yusuf menandai Tuhan Yesus dengan sebutan Imanuel yang artinya Allah beserta kita (Mat. 1:23). Terkait dengan pemahaman Teologi Pentakosta, Daniel Sutoyo menyatakan bahwa Kaum Pentakosta adalah kaum Pentakosta adalah kaum yang memegang teguh Alkitab dan berusaha menyesuaikan kehidupannya dengan Alkitab. (Sutoyo, 2018, p. 167) Pandangan Siahan juga mirip dengan ini yang meyakini bahwa kaum Pentakosta adalah kaum yang mempercayai Alkitab dan meyakini benar bahwa Alkitab tidak mungkin salah. (H. E. Siahaan, 2015, p. 105) Artinya apa yang dicatat Alkitab bagi kaum Pentakosta masih mungkin terjadi. Arrington mengidentifikasi kaum Pentaksota sebagai kaum yang percaya sepenuhnya Alkitab serta memperjelas keberadaan Roh Kudus sebagai Allah Alkitab dan dalam hubungan pribadi dengan orang percaya. (Arrington, 2020, p. 373-374) Jelaslah bahwa kaum Pentakosta membangun pemahaman iman mereka dengan percaya pada Alkitab dan mengandalkan keterlibatan kuasa Roh Kudus berkarya dalam keseharian hidupnya. Lebih jauh penelitian artikel ini ingin memjelaskan bagaimana teologi Pentakosta memaknai gambaran Alkitab tentang penyertaan Allah.

\section{METODE PENELITIAN}

Peneliti dalam mengerjakan penelitian ini menggunakan metode kualitatif dengan pendekatan deskriftif Analitis dan kajian literatur. Metode kualitatif dinilai paling cocok karena karakteristiknya yang bersifat memaknai. (S. E. Zaluchu, 2020b, p. 28) Deskriftif analitis peneliti gunakan untuk menganalisis dan mengambarkan penyertaan Allah baik dalam kehidupan Yusuf, kehidupan Musa, Kehidupan Daniel, maupun dalam diri dan pelayanan Tuhan Yesus sehingga para pembaca artikel ini mendapatkan makna yang mendalam. Selain itu peneliti juga membingkai narasi penyertaan Allah dalam Alkitab ini dari sudut pandang teologi Pentakosta. Sedangkan kajian literatur digunakan untuk memberikan dukungan terhadap pandangan peneliti dari penggalian contoh Alkitab yang diangkat sehingga menambah kokok pandangan peneliti dan dalam kaitan dengan standar akademik yang baik dari artikel jurnal. Adapun kajian literatur yang digunakan dalam penelitian ini adalah dari artikel jurnal seperti tulisan Daniel Sutoyo, Evan Siahaan, Dan Lee Roy Martin serta dari buku semisal tulisan F.L. Arrington. Tentunya kajian literatur yang dipilih dalam artikel ini yang memiliki nilai kebaharuan dan juga memiliki relevansi dengan topik pembahasan. 


\section{HASIL DAN PEMBAHASAN}

\section{Penyertaan Tuhan dalam Kehidupan Yusuf}

Yusuf merupakan pribadi yang menonjol bukan sekedar karena keelokan parasnya maupun kekuatan karakternya malainkan juga terkait bagaimana pengaruh dan peran yang dia mainkan pada awal kehidupan sebuah bangsa panggilan Allah. (Hügel, 2013, p. 69) Penulis kitab Kejadian secara terstruktur mengisahkan bagaimana kehidupan Yusuf seorang anak yang disangat disayang oleh Yakub ayahnya, kemudian mengalami hal yang menyakitkan dihianati dan dijual oleh saudara-saudaranya kepada saudagar Median dengan harga dua puluh syikal perak, yang kemudian dijual sehingga menjadi pelayan dirumah Potirat, di fitnah dan harus masuk penjara tanpa kesalahan bersama dua orang orang kepercayaan Firaun. (Sukono, 2019, p. 28) Di Penjara inilah kemudian yusuf menjadi akrab dengan kedua orang kepercayaan Firaun itu yang membuka jalan kemudian dipanggil Firaun untuk menafsirkan mimpinya dan diangkat jadi perdana Menteri oleh Firaun. (Hendi, 2017, p. 29) Alkitab mengambarkan bahwa Tuhan menyertai Yusuf dan melimpahkan kasih setia-Nya kepada Yusuf sehingga membuat berhasil apa yang dikerjakannya (Kej. 39:21). Penyertaan Tuhan dalam kehidupan Yusuf bahkan bisa dilihat oleh orang-orang yang belum mengenal Allah Abraham waktu itu, namun penyertaan Tuhan inilah yang menjamin keberhasilan yang Yusuf kerjakan.

Cerita Alkitab tentang kehidupan dan bagaimana Tuhan menyertai Yusuf ini oleh Gary Edward Schnittjer dalam bukunya The Torah Story dimaknai dengan apa yang dahulu tampak sebagai kemalangan atau serangkaian panjang petualangan buruk ditafsir oleh pencerita kitab Kejadian sebagai pimpinan dan penyertaan Tuhan. (Schnittjer Edward, 2015, p. 174) Terkait dengan peristiwa yang terjadi dalam kehidupan Yusuf dan penyertaan Tuhan, Wolf berpandangan bahwa kehadiran Allah bersinar dengan jelas memakai kebencian manusia dan menggunakannya untuk menyelamatkan seluruh keluarga itu beserta banyak orang lainnya. (Wolf, 2017, p. 163) Bagi teologi Pentakosta merujuk pada buku Doktrin Kristen Perspektif Pentakosta yang ditulis oleh French L. Arrington bahwa Allah adalah Omnipresence, Dia adalah Tuhan atas ruang dan waktu. (Arrington, 2020, p. 88) Ini artinya dalam pandangan Pentakosta ruang dan waktu tidak akan pernah bisa membatasi Tuhan. (Martin, 2018, p. 1) Terkati dengan penyertaan Tuhan dalam kehidupan Yusuf, dimaknai oleh kaum Pentakosta sebagai campur tangan Tuhan dalam orang pilihan-Nya dan memastikan bahwa tidak ada satupun rencana Tuhan yang akan gagal dan tidak 
ada yang bisa menghentikan rencana itu. Alkitab menjelaskan bahwa Tuhan sendiri yang memastikan rencana itu berhasil.

\section{Penyertaan Tuhan dalam Kehidupan Musa}

Musa merupakan tokoh penting dalam Perjanjian Lama, ketokohan Musa ini Terus bergema digenerasi-generasi selanjutnya bahkan sampai pada masa Tuhan Yesus melayani pun ketokohan musa masih menjadi model acuan. (Manurung, 2020c, p. 94) Kitab Keluaran mengambarkan dengan gamblang bagaimana penyertaan Tuhan dalam kehidupan Musa, pada waktu Firaun penguasa yang waktu itu berkuasa atas Mesir memerintahkan setiap anak laki-laki yang lahir dari bangsa Israel harus dibunuh, Musa selamat tidak dibunuh bahkan malah menjadi pangeran, hidup di istana kerajaan dengan fasilitas hidup serba mantap, dan mengenyam pendidikan dengan standar akademik terbaik waktu itu karena diangkat anak oleh putri Firaun. (Schnittjer Edward, 2015, p. 218) Musa bukanlah orang yang lupa atau sengaja melupakan asal usul identitas dirinya melainkan Musa mengenal benar dari mana dia berasal, Musa secara pribadi juga tidak ingin hal buruk menimpa orang sebangsanya Israel hal inilah yang mendorong muda untuk membunuh orang Mesir yang memukul orang Israel (Kel. 2:1-12). Tindakan Musa membunuh orang Mesir ini mengakibatkan Ia harus melarikan diri dan menjauh dari istana Firaun. (Fitrah, 2019, p. 176)

Allah adalah Allah yang bergerak dengan tujuan artinya Allah tidak mungkin melakukan segala sesuatu secara serampangan, karena iseng saja, asal-asalan saja, melainkan Allah merencanakan dengan matang setiap tindakan yang Dia ingin lakukan.(Manurung, 2020a, p. 129) Allah punya rencana ketika Dia memilih Musa dan menempatkan Musa pada saat dan waktu yang tepat untuk membebaskan umat pilihan-Nya dari perbudakan di Mesir ini dan membawa umat Tuhan untuk terikat dalam Perjanjian dengan Tuhan. (Agung, 2020. p. 1) Tujuan ini adalah tujuan yang sangat besar dan hanya orang yang dipilih Tuhan-lah yang telah mengalami proses pembentukan Tuhan saja yang bisa melakukan tugas pembebasan ini, karena yang akan Musa lakukan bukanlah sekedar tugas pembebasan saja melainkan Musa juga mengikatkan umat Tuhan kepada Allah Israel dalam sebuah perjanjian. (Frankiv, 2020, p. 52) Lasor mengomentari tentang perjanjian yang dibuat oleh Allah dengan bangsa Israel melalui Musa dan membandingkan itu dengan apa Perjanjian Allah dengan musa bahwa ketika Allah membuat perjanjian dengan Abraham, Allah menempatkan diri-Nya dibawah kewajiban, sedangkan dalam Perjanjian dengan 
Musa bangsa Israel yang menerima perjanjian dituntut untuk bersumpah dan karena itu ditempatkan dibawah peraturan yang ketat. (LASOR, HUBBARD, \& BUSH, 2015, p. 169) Siahaan dalam tulisannya tentang Karakteristik Pentakostalisme menyatakan bahwa kaum Pentakosta adalah kaum yang tekun, antusias, rendah hati dan bersemangat dalam melayani Tuhan. (Siahaan, 2017, p. 12) Jadi membingkai pernyataan Siahaan dalam kaitan dengan penyertaan Allah dalam kehidupan musa ini sebagai peran serta Allah dalam rangka mempersiapkan dan menyertai hamba-Nya untuk suatu tugas yang membutuhkan proses pembentukan, ketekunan, antusias, keberanian, kerendahan hati dan sifat melayani, agar tugas besar untuk membebaskan bangsa Israel dan membawa masuk ke tanah perjanjian serta mengikatkan hati umat kepada Allah ini bisa terlaksana.

\section{Penyertaan Tuhan dalam Kehidupan Daniel}

Penyertaan Tuhan dalam kehidupan daniel adalah contoh penyertaan Tuhan lainnya yang dicatat oleh Alkitab yang banyak menarik perhatian orang percaya untuk berhenti sejenak dan merenungkan betapa ajaib dan dahsyatnya Tuhan yang Daniel dan orang percaya sembah. (Setio, 2019, p. 211) Daniel adalah salah seorang anak muda tawanan perang yang dibawa ke Babel ketika raja Babilonia Baru bernama Nebukadnezar menyerang, menaklukan, dan meluluh lantahkan Yerusalem sekitar tahun 586SM yang waktu itu menjadi ibu kota kerajaan Yehuda (Israel Selatan). (B. Coote, 2014, p. 1) Namanya tawanan perang dan seorang yang masih muda pula, Daniel selama perjalanan panjang dari Yerusalem ke Babel pastinya mengalami banyak penderitaan, rasa kehilangan, kenangan akan kenyamanan hidup, terlepas dari lingkungan yang dikenal selama ini, dan ketakutan harus masuk dalam sebuah situasi baru dimana semuanya yang terlihat hanyalah penderitaan dan kesengsaraan. (KALAMPUNG, 2019, p. 170) Dalam kondisi seperti ini tangan Tuhan yang tidak kelihatan membuka jalan bagi Daniel dan ketiga temannya lewat perekrutan untuk bekerja di Istana raja (Dan. 1:3-6).

Tuhan menyertai Daniel dan telah membuka pintu bagi Daniel untuk menduduki kursi berpengaruh di kerajaan Babel sebagai orang kepercayaan raja, namun bukan berarti semuanya seperti jalan tol yang bebas dari macet dan hambatan lainnya, seperti kata pepatah bangsa kita semakin tinggi pohon makan semakin kencang anginnya, hal serupa juga terjadi dalam kehidupan Daniel. (Benyamin, 2019, p. 48) Daniel menjadi korban politik praktis waktu itu dimana dia menjadi korban fitnah dari para lawan politik yang iri dan haus akan kekuasaan serta mengincar 
kursi dan kekuasaan yang diberikan oleh raja kepada Daniel, atas perintah raja Daniel dibuang ke gua yang berisi singa lapar (Dan. 6: 16-17). Namun Tuhan Allah yang Daniel sembah tidak tinggal diam lewat cara yang ajaib Dia menyelamatkan Daniel, singa-singa yang lapar tidak memakan Daniel dan lewat peristiwa gua singa ini raja mengakui kemaha kuasaan Allah dan menyuruh setiap orang yang dibawah kekuasaannya menghormati Allah yang disembah oleh Daniel (Dan. 6: 2628). (Nainggolan, 2019, p. 11) Yushak Soesilo dalam artikel penelitiannya tentang Pentakostalisme dan aksi sosial menyatakan bahwa gerakan pentakostalisme adalah gerakan yang berusaha mengembalikan kekristenan yang Alkitabiah dan yang menitik beratkan pada kuasa serta karya dari Roh Kusud. (Soesilo, 2018, p. 136) Susanne Rodemeier dalam penelitiannya tentang Gereja Pentakosta-Karismatik di Jawa menemukan bahwa iman merupakan hal yang penting bagi kalangan Pentakosta-karismatik. (Rodemeier, 2016, p. 40) Apabila dalam memaknai kisah Daniel yang mengalami mujizat, perlindungan ilahi, serta promosi dari Tuhan peneliti membingkai pandangan Soesilo dan temuan hasil penelitian Rodemeir maka bagi kalangan pentekosta kisah Daniel ini menjadi inspirasi iman untuk terus percaya dan berharap pada Tuhan sang pemberi dan pemilik kehidupan.

\section{Pelayanan yang Tuhan Yesus Lakukan}

Yusuf didatangi oleh malaikat Tuhan dalam mimpi dan diberitahu bahwa anak yang dikandung oleh maria adalah dari Roh Kudus dan yang anak menyelamatkan umat-Nya dari dosa mereka, lebih jauh malaikat Tuhan menyatakan bahwa Dia akan dipanggil Imanuel yang berarti Allah beserta kita (Mat. 1:20-23). Istilah Imanuel sendiri merupakan istilah yang sepertinya sudah dipahami secara umum pada masyarakat waktu itu yang hanya merujuk pada Mesias seperti yang dinubuatkan oleh para nabi di Perjanjian Lama. (Manurung, 2020a, p. 129) Lewat ayat ini penulis kitab Matius mencoba membangun sebuah narasi tentang diri bayi yang akan dilahirkan Maria bahwa melalui bayi keberadaan Tuhan menjadi nyata bagi bangsa Israel sebagai umat pilihan Tuhan atau dengan kata lain dengan lahirnya bayi itu dan kehidupannya ditengah umat pilihan adalah seperti kehadiran dan penyertaan Allah sendiri ditengah umat-Nya. (Cristian Runturambi, 2018, p. 41) Hal ini berarti kehadiran Yesus dimuka bumi waktu itu setara dengan kehadiran dan penyertaan Allah dimasa lalu yang umat pilihan pernah rasakan, alami, dan pahami. (Sihaloho, 2018, p. 12) 
Gambaran paling sempurna dari penyertaan Tuhan dalam kehidupan umat-Nya adalah apa yang Tuhan Yesus kerjakan selama masa pelayanan-Nya dimuka bumi ini. (Wicaksono \& Anggono, 2019, p. 142) Menelaah secara seksama bagaimana Tuhan Yesus hidup dan melayani terlihat jelas bahwa panggilan Imanuel yang dikumandangkan oleh malaikat Tuhan bukanlah hanya sebutan kosong belaka. Melainkan bisa disimpulkan bahwa setiap harinya hal ini digenapi dengan sempurna dalam kehidupan dan pelayanan Tuhan Yesus sewaktu hidup secara khusus dalam pelayanan yang Dia kerjakan. (Susanto, 2020, p. 78) Zaluchu sebagai pengajar dan teolog Pentakosta menyatakan puncak dari hati Tuhan yang ingin selalu menyertai dan bersama umatNya adalah ketika Tuhan menyerahkan nyawa-Nya dikayu salib untuk menebus dosa orang berdosa supaya diselamatkan dan menghabiskan kekekalan bersama Tuhan. (S. Zaluchu, 2018, p. 24) Daniel Sutoyo dalam artikelnya tentang analisis historis terhadap gerakan teologi Pentakosta menyatakan bahwa iman pantekosta meletakan bahwa Alkitab merupakan rujukan utama untuk bersekutu dengan Allah dan memahami dunia. (Sutoyo, 2018, p. 167) Bagi kaum Pentakosta yang mengimani benar bahwa seluruh Alkitab adalah kebenaran dan pernyataan Allah maka terkait dengan kehidupan dan pelayanan Tuhan Yesus selama melayani di bumi dimaknai sebagai contoh dari kehadiran dan cinta Allah bagi manusia secara khusus bagi orang percaya dimana kerinduan terdalam dari hati Allah yang ingin selalu bersekutu dengan umat-Nya.

\section{Pemaknaan Penyertaan Allah Dalam Bingkai Teologi Pentakosta}

\section{Kehadiran Allah}

Penyertaan Allah adalah kehadiran Allah dalam kehidupan orang percaya. (Adiprasetya, 2020, p. 127) Kemaha hadiran Allah bukan sekedar gelar belaka melainkan itu adalah sebuah tindakan nyata yang selalu Allah lakukan. (Naat, 2020, p. 1) Kaum Pentakosta menyadari benar seperti yang digambarkan oleh Alkitab bahwa dosa kejatuhan manusia di taman Eden telah menyeret manusia dalam sebuah kondisi keterpisahan dari Allah dan dampak keterpisahan dari Allah ini membuat kehidupan manusia dari generasi ke gerenasi semakin dipenuhi dengan bergabai kejahatan, kesengsaraan, maupun penderitaan lainnya. (Manurung, 2020b, p. 307) Kehadiran Allah mutlak dibutuhkan untuk memperbaiki kondisi hidup manusia dan dimana manusia hidup yang semakin kacau. (Lie \& Lie, 2017, p. 63) Hal ini tergambar dengan jelas dari persfektif Perjanjian Baru dalam maksud kedatangan Tuhan Yesus yang mengambil rupa manusia dan hidup ditengah manusia dengan maksud utama untuk mati bagi pelanggaran dan dosa manusia agar melalui 
kematian itu manusia bisa mengalami pemulihan dalam hubungan persekutuan Allah. (Lelono, 2017, p. 107) Kaum Pentekosta memaknai penyertaan Allah baik itu dalam kehidupan Yusuf seperti yang sudah dibahas pada bagian sebelumnya maupun kehidupan dan pelayanan yang Tuhan Yesus lakukan selama dimuka bumi sebagai gambaran dari kehadiran Allah bagi umat-Nya.

\section{Pemeliharaan Allah}

Manusia adalah mahluk hidup dengan berbagai keterbatasan diri semisal terbatas dalam hal kemampuan, terbatas dalam hal koneksi, terbatas dalam hal fisik, dan banyak keterbatasan lainnya. (Arifianto, 2020, p. 12) Kadang peneliti melihat untuk mencukupi kebutuhan hidup yang paling dasar berupa sandang, pangan, dan papan ada banyak orang saat ini masih belum bisa memenuhi itu dengan layak. (Farida, 2017, p. 51) Alkitab memberikan gambaran bahwa penyertaan Allah juga berarti pemeliharaan Allah atas seluruh kehidupan orang percaya. (Manurung, 2021, p. 8; Wijaya, 2016, p. 109) Penyertaan Allah dalam kehidupan Yusuf berdampak juga bukan hanya pada kemajuan dan kesuksesan hidup Yusuf secara pribadi melainkan juga bagaimana melalui keberhasilan Yusuf ini, anak cucu Yakub sebagai cikal-bakal bangsa pilihan Tuhan terpelihara dan terhindar dari bencana kematian yang sedang melanda seluruh negri waktu itu. Kitab Injil mencatat bagaimana Tuhan Yesus waktu masih melayani melakukan mujizat dari lima roti dan dua ikan untuk mengenyangkan lima ribu laki-laki belum termasuk anak-anak yang kelaparan sewaktu mendengarkan Tuhan mengajar (Luk. 9:10-17). Bobby K. Putrawan dalam artikel jurnalnya tentang pengantar teologi Pentakosta menyatakan bahwa kaum Pentakosta mengkhotbahkan mujizat Allah dialkitab termasuk juga tentunya kesembuhan ilahi maupun pemeliharaan Allah karena kaum Pentaksota meyakini bahwa mujizat Allah disediakan bersamaan dengan penebusan Kristus dan menjadikan hal ini hak istimewa orang percaya. (Putrawan, 2019, p. 4) Tindakan Tuhan yang memelihara umat pilihan seperti memeliharan anak cucu Yakub maupun memberi makan lima ribu orang dan banyak lagi contoh lain yang ditulis Alkitab dimaknai oleh orang percaya dari kalangan Pentakosta merupakan bagian dari pemeliharaan Tuhan. Sebagai orang percaya masa kini kesadaran akan keterbatasan yang kita miliki sebagai manusia seharusnya menarik kita untuk semakin mempercayai penyertaan dan pemeliharaan Allah. 


\section{Perlindungan Allah}

Dosa mengakibatkan manusia dipenuhi nafsu jahat dan berbagai hal jahat lainnya yang kadang demi memuaskan nafsu maupun kepentingannya bahkan rela melakukan apa saja termasuk berbuat tindak kejahatan terhadap sesama. (Wasiyona, 2019, p. 79) Adalah tindakan yang bijak apabila orang percaya mengikuti yang disarankan Alkitab untuk mencari Allah dan memohon perlindungan-Nya agar terhindar dari yang jahat. (Samarenna, 2019, p. 15) Alkitab juga menjelaskan bahwa penyertaan Allah berarti perlindungan Allah. Ketika Mesir mengalami sepuluh tulah bangsa Israel yang pada waktu itu tinggal di daerah Mesir juga tidak mengalami sedikitpun dari tulah-tulah itu, melainkan mendapatkan keuntungan dan mereka bisa minta dari orang mesir barang-barang berharga waktu mereka mau keluar menuju tanah perjanjian. (S. E. Zaluchu, 2020a, p. 267) Ketika Allah menyertai Daniel, Allah juga melindungi Daniel dari terkaman singa lapar dan Allah membela Daniel dari para pemfitnahnya dengan menunjukan perlindungan-Nya (Dan. 6: 1-29). Marius Nel seorang teolog Pentakosta menyatakan bahwa kaum Pentakosta dalam praktiknya meyakini bahwa yang apa yang mereka lakukan seperti masa gereja mula-mula lakukan, masih menurut Marius Nel karena kaum Pentakosta beranggapan bahwa gereja mula-mula adalah buah karya dari Roh Kudus daa kaum Pentakosta dalam membaca alkitab menggunakan lensa karya Roh Kudus. (Nel, 2020, p. 1) Memahami Penyertaan Allah adalah intisari dari iman Kristen yang bagi kaum Pentakosta diaplikasikan dengan pemaknaan bahwa Allah menyertai seluruh aktivitas kehidupan keseharian orang percaya dan dimana ada pernyertaan Allah pasti ada perlindungan-Nya.

\section{Membangkitkan Keyakinan}

Pengetahuan, pengetahuan, pemahaman biasanya terkoneksi dengan sikap dan perilaku. Ketika seseorang memahami sesuatu maka ada pemahaman yang berubah dari orang tersebut. Misalnya ketika orang percaya tahu Allah sedang bersamanya maka keberanian akan muncul dalam diri orang tersebut. Penyertaan Allah dalam kehidupan orang percaya ini kemudian memberikan pemahaman yang membangkitkan keyakinan orang percaya untuk semakin mempercayai Allah dan berpegang teguh pada janji-janji-Nya. (Handayani, 2018) Keyakinan ini berupa kekuatan untuk meyakini bahwa Allah sedang ada bersama dalam kondisi yang sedang dialami. Dilemparkan ke gua yang berisi singa-singa kelaparan tidak membuat Daniel berhenti mempercayai Allah karena Daniel yakin benar bahwa Allah bersertanya, malah lewat peristiwa itu Daniel mengalami 
perlindungan dan pembelaan Allah. (Nainggolan, 2019, p. 11-21) Yusuf mengalami berbagai hal yang menyakitkan dari di jual keluarga sampai di penjara, yang dalam sudut pandang manusia tidak ada harapan lagi karena didakwa melecehkan istri Potifar seorang pejabat tinggi Mesir, namun Allah menyertai Yusuf sehingga rancangan jahat yang coba menjatuhkan Yusuf justru Allah pakai untuk mengangkat Yusuf karena ketika dipenjaralah Yusuf membangun berkesempatan membangun akses ke Firaun lewat kepala juru minum. (Hendi, 2017, p. 29) Kalangan Pentakosta memaknai penyertaan Allah dalam kehidupan Yusuf, Daniel dan pahlawan iman lainnya yang dicatat Alkitab sebagai pemantik yang mengaktifkan iman dalam diri orang percaya untuk mempercayai dan terus berpaut pada Allah. Hendarto Supatra dalam artikel jurnalnya tentang mengenal Pentakosta di Indonesia mengungkapkan bahwa sekalipun kaum Pentaksota mengutamakan karya Roh Kudus bukan berarti kaum pentakosta mengesampingkan Allah Bapa dan Tuhan Yesus Kristus, bahkan masih menurut Supatra Pentakostalisme akan menjadi wadah kekristenan di masa depan. (Supatra, 2019, p. 11)

\section{KESIMPULAN}

Alkitab memberikan gambaran tentang kerinduan Allah untuk menyertai orang pilihannya. Hasil penelitian ini memaparkan bahwa penyertaan Allah merupakan kerinduan hati Allah untuk hadir dalam keseharian hidup orang percaya sebagai umat pilihan-Nya. Teologi Pentakosta melihat bahwa penyertaan Allah sebagai kehadiran Allah ditengah umat-Nya untuk memelihara dan melindungi umat pilihan-Nya yang dalam konteks sekarang adalah orang percaya. Pemahaman akan penyertaan Allah ini membangkitkan iman untuk dengan yakin mempercayai dan hidup bagi Allah. Lewat penyertaan Allah dalam kehidupan hamba-hamba-Nya seperti Yusuf, Musa, Daniel maupun lewat penyertaan langsung yang dirasakan orang percaya di Perjanjian Baru seperti yang digambarkan para penulis Injil lewat diri dan pelayanan Tuhan Yesus. Kesemua ini semakin membuktikan bahwa Allah selalu menyertai umat-Nya dan tidak akan pernah meninggalkan orangorang pilihan-Nya. Kiranya artikel ini bisa menjadi berkat dan membangkitkan keyakinan iman orang percaya masa kini untuk terus berpaut pada Allah dan memohon penyertaan-Nya. Bagi para peneliti semoga artikel ini bisa jadi pemicu untuk melahirkan penelitian-penelitian yang sejenis maupun yang beririsan dengan tema sehingga semakin memperkaya ilmu teologi atau barang kali bisa dijadikan referensi akademik. 


\section{DAFTAR PUSTAKA}

Adiprasetya, J. (2020). Dari Tangga ke Taman: Multiplisitas Pertumbuhan Iman dan Implikasinya bagi Karya Pedagogis, Pastoral, dan Liturgis Gereja. DUNAMIS: Jurnal Teologi Dan Pendidikan Kristiani, 4(2), 127-142. https://doi.org/10.30648/dun.v4i2.232 Agung, W. (2020). Kepemimpinan Multistaf Menurut Keluaran 18:13-27Dan Implikasinya Bagi Pemimpin Gereja Masa Kini. SABDA: Jurnal Teologi Kristen, 1(1), 1-12. Retrieved from http://jurnalsttn.ac.id/index.php/SJT/article/view/3

Arifianto, Y. A. (2020). Kajian Biblikal tentang Manusia Rohani dan Manusia Duniawi. Jurnal Teruna Bhakti, 3(1), 12-24.

Arrington, F. L. (2020). Doktrin Kristen Perspektif Pentakosta. Yogyakarta: ANDI Offset. B. Coote, R. (2014). Sejarah Deuteronomistik. Jakarta: BPK Gunung Mulia.

Benyamin, N. C. (2019). Doa Dan Harapan Akan Allah Yang Membebaskan Sebuah Tafsiran Post-Kolonial Daniel 9:1-27. Jurnal Abdiel: Khazanah Pemikiran Teologi, Pendidikan Agama Kristen, Dan Musik Gereja, 3(1), 48-59.

Cristian Runturambi, M. (2018). Makna Teologi Perayaan Natal Yesus Kristus. Tumou Tou, VI(1), 41-58. Retrieved from http://ejournal-iaknmanado.ac.id/index.php/tumoutou/article/view/79/153

Farida, F. (2017). Ragam Kebutuhan Manusia Terpenuhi Dengan Komunikasi Lintas Budaya. AtTabsyir: Jurnal Komunikasi Penyiaran Islam, 5(1), 51. https://doi.org/10.21043/attabsyir.v5i1.3151

Fitrah, A. N. (2019). Implementasi Gaya Kepemimpinan Nabi Musa A.S Dalam Pendidikan Karakter. Tawazun: Jurnal Pendidikan Islam, 11(2), 176. https://doi.org/10.32832/tawazun.v11i2.1671

Frankiv, D. (2020). The narrative of Decalogue as an integrated expression of the basic principle of formation of Jewish law. Ukrainian Religious Studies, (90), 52-70. https://doi.org/10.32420/2020.90.2118

Handayani, D. (2018). Tinjauan Teologis Konsep Iman dan Perbuatan Bagi Keselamatan. EPIGRAPHE: Jurnal Teologi Dan Pelayanan Kristiani, 1(2), 91. https://doi.org/10.33991/epigraphe.v1i2.16

Hannas, H., \& Rinawaty, R. (2019). Apologetika Alkitabiah tentang Penciptaan Alam Semesta 
dan Manusia terhadap Kosmologi Fengshui sebagai Pendekatan dalam Pekabaran Injil. DUNAMIS: Jurnal Teologi Dan Pendidikan Kristiani, 4(1), 55-74. https://doi.org/10.30648/dun.v4i1.206

Hendi, H. (2017). Empat Peristiwa Penting Di dalam Kehidupan Yusuf: Sebuah Kajian Terhadap Kecerdasan Yusuf. DUNAMIS: Jurnal Penelitian Teologi Dan Pendidikan Kristiani, 2(1), 29. https://doi.org/10.30648/dun.v2i1.130

Hügel, K. (2013). A Queer Reading of Joseph: Jewish Interpretations of the Beautiful Young Man in the Hebrew Bible. Biblische Notizen, 157, 69-99. Retrieved from https://www.unet.univie.ac.at/ a9104666/huegelkarinarticlejoseph.html

Kalampung, Y. O. (2019). “Ketika Memori Penderitaan Diperjumpakan” Sebuah Kajian Dialogis Kitab Daniel dan Sejarah Penjajahan Jepang di Indonesia dalam Perspektif Poskolonial. KENOSIS: Jurnal Kajian Teologi, 4(2), 170-185. https://doi.org/10.37196/kenosis.v4i2.66

LASOR, W. S., HUBBARD, D. A., \& BUSH, F. W. (2015). PENGANTAR PERJANJIAN LAMA 1. Jakarta: BPK Gunung Mulia.

Lelono, M. J. (2017). Yesus Kristus Sang Jalan : Kristologi Kontekstual Bagi Penghayat Kebatinan Katolik. Jurnal Teologi, 4(2), 107-120. Retrieved from https://webcache.googleusercontent.com/search?q=cache:og042PPwa8kJ:https://ejournal.usd.ac.id/index.php/jt/article/view/469/408+\&cd=5\&hl=id\&ct=clnk\&gl=id

Lie, H. D., \& Lie, H. D. (2017). Penggenapan Progresif Misi Allah Dalam Kisah Para Rasul 1:8. Jurnal Jaffray, 15(1), 63. https://doi.org/10.25278/jj71.v15i1.235

Lumingkewas, M. S. (2019). One God or One Lord? Deuteronomi and the Meaning of Monotheism. FIDEI: Jurnal Teologi Sistematika Dan Praktika, 2(2), 388-410. https://doi.org/10.34081/fidei.v2i2.79

Manurung, K. (2019). Studi Analisis Kontekstual Ajaran Karunia Nubuat Rasul Paulus sebagai Dasar Evaluasi Kritis terhadap Fenomena Bernubuat di Gereja Beraliran Karismatik. DUNAMIS: Jurnal Teologi Dan Pendidikan Kristiani, 4(1), 37-54. https://doi.org/10.30648/dun.v4i1.189

Manurung, K. (2020a). Ketubim dan Nubuat. Pengarah: Jurnal Teologi Kristen, 2(2), 129-140. https://doi.org/10.36270/pengarah.v2i2.24

Manurung, K. (2020b). Memaknai Kemarahan Allah Dari Sudut Pandang Teologi Pentakosta Di Era Post Modern. Visio Dei: Jurnal Teologi Kristen, 2(2), 307-328. 
https://doi.org/https://doi.org/10.35909/visiodei.v2i2.162

Manurung, K. (2020c). Taurat dan Nubuat Palsu: Kajian Sudut Pandang Taurat Terhadap Nubuat Palsu. Jurnal Teologi Berita Hidup, 2(2), 94-109. https://doi.org/10.38189/jtbh.v2i2.31 Manurung, K. (2021). Telaah Teologi Pentakosta Memaknai Pemeliharaan Allah Bagi Orang Percaya Di Masa New Normal. Filadelfia Jurnal Teologi Dan Pendidikan Kristen, 2(1), 8 24. Retrieved from http://e-journal.sttimanuelpacet.ac.id/index.php/filadelfia

Martin, L. R. (2018). Characteristics of Pentecostal Biblical Hermeneutics. Pharos Journal of Theology, 99(1-9). Retrieved from https://www.pharosjot.com/uploads/7/1/6/3/7163688/article_1_vol_99_2018.pdf

Naat, D. E. (2020). Tinjauan Teologis-Dogmatis Tentang Sakramen Dalam Pelayanan Gerejawi. Pengarah: Jurnal Teologi Kristen, 2(1), 1-14. https://doi.org/10.36270/pengarah.v2i1.18

Nainggolan, B. D. (2019). Analisis Ajaran Kitab Daniel Pasal 4 Pengakuan Raja Nebukadnezar Tentang Kuasa Allah Daniel. Jurnal Koinonia, 11(2), 11-21. Retrieved from https://jurnal.unai.edu/index.php/koinonia/article/view/2350/1708

Nel, M. (2020). Pentecostal canon of the bible? Journal of Pentecostal Theology, 29(1), 1-15. https://doi.org/10.1163/17455251-02901001

Pradipta, N. (2019). Belas Kasih Allah dalam Kematian Kristiani Menurut Karl Rahner. Jurnal Teologi, 8(1), 47-64. https://doi.org/10.24071/jt.v8i1.1588

Putrawan, B. K. (2019). Pengantar Teologi Pantekosta. QUAERENS: Journal of Theology and Christianity Studies, 1(1), 1-7. https://doi.org/10.46362/quaerens.v1i1.2

Rodemeier, S. (2016). Kajian Atas Gereja Pentakosta-Kharismatik di Jawa, Indonesia: Sebuah Tantangan. GEMA TEOLOGIKA, 1(1), 31. https://doi.org/10.21460/gema.2016.11.210

Rouw, J. F. (2017). Kajian Konseptual Tentang Pemilihan Allah Dalam Roma 9. Evangelikal: Jurnal Teologi Injili Dan Pembinaan Warga Jemaat, 1(2), 170. https://doi.org/10.46445/ejti.v1i2.76

Samarenna, D. (2019). Tinjauan Teologi “Allah Kota Benteng” Dalam Mazmur 46:1-12. PASCA : Jurnal Teologi Dan Pendidikan Agama Kristen, 15(2), 15-21. https://doi.org/10.46494/psc.v15i2.53

Schnittjer Edward, G. (2015). THE TORAH STORY. Malang: Gandum Mas.

Setio, R. (2019). Penguasa, Tuhan, dan Rakyat: Membaca Apokalips Daniel 7 sebagai Subversi. GEMA TEOLOGIKA: Jurnal Teologi Kontekstual Dan Filsafat Keilahian, 4(2), 211. 
https://doi.org/10.21460/gema.2019.42.481

Siahaan, H. E. (2015). Memahami Pentakostalisme Melalui Bingkai Historiografi Lukas Dalam Kisah Para Rasul. Antusias Jurnal Teologi Dan Pelayanan, 4(7), 105-126. Retrieved from https://www.sttintheos.ac.id/e-journal/index.php/antusias/article/view/6

Siahaan, H. E. R. (2017). Karakteristik Pentakostalisme Menurut Kisah Para Rasul. DUNAMIS: Jurnal Penelitian Teologi Dan Pendidikan Kristiani, 2(1), 12. https://doi.org/10.30648/dun.v2i1.132

Sihaloho, H. (2018). Nubuatan Tentang Mesias dalam Perjanjian Lama Berdasarkan Kitab Sejarah. Kurios, 3(1), 12. https://doi.org/10.30995/kur.v3i1.25

Soesilo, Y. (2018). Pentakostalisme dan Aksi Sosial: Analisis Struktural Kisah Para Rasul 2:4147. DUNAMIS: Jurnal Teologi Dan Pendidikan Kristiani, 2(2), 136-151. https://doi.org/10.30648/dun.v2i2.172

Sukono, D. (2019). Alkitab: Penyataan Allah Yang Diilhamkan. PASCA : Jurnal Teologi Dan Pendidikan Agama Kristen, 15(1), 28-34. https://doi.org/10.46494/psc.v15i1.66

Supatra, H. (2019). Mengenal Pentakostalisme Di Indonesia. Jurnal Abdiel: Khazanah Pemikiran Teologi, Pendidikan Agama Kristen, Dan Musik Gereja, 3(2), 11-24. https://doi.org/10.37368/ja.v3i2.97

Susanto, H. (2020). Yesus sebagai Anak Allah Menurut Injil Matius dan Implementasinya dalam Berapologetika. Logia, 1(1), 78-95. https://doi.org/10.37731/log.v1i1.21

Sutoyo, D. (2018). Analisis Historis terhadap Teologi Gerakan Pentakostalisme. DUNAMIS: Jurnal Teologi Dan Pendidikan Kristiani, 2(2), 167. https://doi.org/10.30648/dun.v2i2.171

Tamrin, A. (2019). Relasi Ilmu, Filsafat dan Agama Dalam Dimensi Filsafat Ilmu. SALAM: Jurnal Sosial Dan Budaya Syar-I, 6(1), 71-96. https://doi.org/10.15408/sjsbs.v6i1.10490

Tembay, A. E., \& Eliman. (2020). Merajut Anugerah Dalam Penginjilan Holistik. SCRIPTA: Jurnal Teologi Dan Pelayanan Kontekstual, 7(1), 33-49. https://doi.org/10.47154/scripta.v7i1.59

Wasiyona, N. (2019). Memahami Teologi Paulus tentang Dosa. SOTIRIA (Jurnal Teologi Dan Pelayanan Kristiani), 2(2), 79-87. Retrieved from http://sttpaulusmedan.ac.id/ejournal/index.php/sotiria/article/viewFile/12/10

Wicaksono, A., \& Anggono, D. (2019). Yesus, Hamba Allah Yang Menderita. FIDEI: Jurnal Teologi Sistematika Dan Praktika, 2(1), 142-158. https://doi.org/10.34081/fidei.v2i1.44 
Wijaya, H. (2016). Pengenaan Manusia Baru Di Dalam Kristus: Natur, Proses, Dan Fakta Serta Implikasi Teologis Dan Praktisnya. Jurnal Jaffray, 14(1), 109. https://doi.org/10.25278/jj71.v14i1.194

Wolf, H. (2017). Pengenalan Pentateukh. Malang: Gandum Mas.

Xiao, A. (2018). Konsep Interaksi Sosial Dalam Komunikasi, Teknologi, Masyarakat. Jurnal Komunika : Jurnal Komunikasi, Media Dan Informatika, 7(2), 94-99. https://doi.org/10.31504/komunika.v7i2.1486

Zaluchu, S. (2018). Sudut Pandang Etika Kristen Menyikapi Pembangkangan Sipil (Civil Disobedience). DUNAMIS: Jurnal Teologi Dan Pendidikan Kristiani, 3(1), 24. https://doi.org/10.30648/dun.v3i1.176

Zaluchu, S. E. (2020a). Pendekatan Reader Response Criticism terhadap Narasi Tulah di Mesir dalam Peristiwa Keluaran. Religious: Jurnal Studi Agama-Agama Dan Lintas Budaya, 4(4), 267-276. https://doi.org/10.15575/rjsalb.v4i4.9206

Zaluchu, S. E. (2020b). Strategi Penelitian Kualitatif dan Kuantitatif Di Dalam Penelitian Agama. Evangelikal: Jurnal Teologi Injili Dan Pembinaan Warga Jemaat, 4(1), 28. https://doi.org/10.46445/ejti.v4i1.167 